\title{
MODEL SEKOLAH ALAM DI SURAKARTA
}

\section{Dhani Mutiari}

Program Studi Arsitektur

Fakultas Teknik UMS

e-mail: dhani.mutiari@ums.ac.id

\section{Kartika Juni Fardani}

Program Studi Arsitektur

Fakultas Teknik UMS

e-mail: kartika.jf@gmail.com

\begin{abstract}
ABSTRAK
Profil pendidikan di Indonesia dewasa ini masih banyak yang mempunyai karakteristik bersifat centris dalam arti pendidikan untuk melanjutkan sekolah, tidak mempunyai makna untuk menyongsong kehidupan di masa depan. Sistem pembelajaran yang selama ini dilakukan bersifat konvensional dan kurang sesuai dengan dinamika perkembangan ilmu pengetahuan dan teknologi yang demikian pesat karena kental dengan suasana instruksional. Paper ini bertujuan untuk mencari model sekolah alam yang sesuai dengan masyarakat Surakarta dan menjadi tempat penitipan sekaligus pendidikan dan bermain bagi anak-anak usia dini. Sekolah alam adalah salah satu bentuk pendidikan alternatif yang menggunakan alam sebagai media utama sebagai pembelajaran siswa didiknya. Metode belajar mengajar di sekolah alam lebih banyak menggunakan aktif atau action learning dimana anak belajar melalui pengalaman secara langsung. Penggunaan metode ini anak atau siswa diharapkan belajar dengan lebih bersemangat, tidak bosan, dan lebih aktif. Selain mendapat pendidikan dengan baik, anak juga perlu bermain sambil berekreasi yang dapat mengembangakan bakat serta kreativitasnya. Metode penelitian ini kualitatif dengan pendekatan studi komparasi dengan sekolah alam yang telah ada di Ciganjur, Bali, Surabaya dan Surakarta. Model yang dikembangkan disain ini adalah sekolah alam yang merupakan suatu wadah yang dapat menampung semua aktivitas dalam satu wadah yaitu Children Actvity Center. Children Activity Center merupakan fasilitas edukasi berbasis alam di Surakarta dengan kegiatan utama berupa pengasuhan anak, edukasi, rekreasi, sosialisasi serta penyaluran bakat dan kreativitas yang dapat mendukung pertumbuhan anak baik secara fisik maupun mental dengan pendekatan alternatif pendidikan berbasis alam. Kegiatan utama berupa pendidikan difokuskan pada anak usia dini yaitu 3-6 tahun sedangkan kegiatan pengasuhan diperuntukkan untuk anak usia 1 hingga 2 tahun. Disain yang dihasilkan adalah tata masa dengan pola radial dengan pusat ruang terbuka berupa tanaman hias untuk estetika selain area farming. Terdapat kelas dengan konsep saung menggunakan material kayu dan bambu serta outbond area yang bermanfaat untuk mendekatkan diri dengan alam. Konsep bangunan bambu menjadi pilihan untuk penampilan fasadenya.
\end{abstract}

KATA KUNCI: pendidikan anak; sekolah alam; Surakarta

\section{PENDAHULUAN}

Menurut Ahmad Hamadani (2015) sekolah dipercaya sebagai tempat untuk memperoleh pendidikan yang menghadirkan lingkungan aman dan nyaman bagi peserta didik. Namun, data dari riset yang dilakukan LSM Plan International dan International Center for Research on Women (ICRW) yang dirilis awal Maret 2015 menunjukan, bahwa $84 \%$ anak di Indonesia mengalami kekerasan di sekolah, hal ini disebabkan minimnya sekolah yang hadir dengan membawa konsep lingkungan ramah anak. Oleh karena itu, Indonesia perlu memiliki sekolah tidak hanya dengan konsep pendidikan unggul, namun juga dapat menghadirkan lingkungan ramah anak.
Secara umum profil pendidikan di Indonesia masih mempunyai karakteristik yang tekstual, berorientasi ke produk dengan mengabaikan proses, fokus pada evaluasi akhir tanpa menggunakan evaluasi portofolio sebagai ukuran kemajuan siswa, berorientasi ke IQ tanpa menyentuh pengembangan kreativitas (CQ), emosional (EQ) dan spiritual (SQ) lebih-lebih kearah AQ. Pendidikan kita sekarang ini juga bersifat centris sekolah, dalam arti pendidikan untuk melanjutkan sekolah, tidak mempunyai makna untuk menyongsong kehidupan di masa depan. Secara ekstrem dapat dikatakan bahwa pendidikan kita masih membelenggu, belum membebaskan dan menyenangkan. Sistem pembelajaran yang selama ini dilakukan yaitu sistem pembelajaran konvensional (faculty teaching), kurang sesuai dengan dinamika 
perkembangan ilmu pengetahuan dan teknologi yang demikian pesat karena kental dengan suasana instruksional. Pendidikan dituntut untuk memasukkan nilai-nilai moral, budi pekerti luhur, kreatifitas, kemandirian dan kepemimpinan, yang sangat sulit dilakukan dalam sistem pembelajaran yang konvensional.

Model sekolah alam ini menurut Rohinah (2014) memiliki tiga aspek khusus, yakni: alam sebagai ruang belajar, alam sebagai media dan bahan mengajar, serta alam sebagai objek pembelajaran. Pendidikan seperti ini merupakan sebuah kreativitas dalam membangun paradigma pendidikan Islam yang humanis. Pada dasarnya sekolah alam adalah sebuah upaya untuk beralih dari kultur pendidikan yang umum ada di Indonesia, dimana sebagian besar hanya berlangsung di dalam kelas dan juga sebagian besar masih menerapkan pembelajaran konvensional. Anak hanya belajar secara teoritis, tanpa pernah mempraktekkan langsung pengetahuannya. Cara belajar ini dianggap pasif karena hanya mempelajari apa yang ada di buku atau diajarkan guru. IImu pengetahuan yang dimiliki anak hanyalah hafalan belaka, bukan pemahaman menyeluruh yang diperoleh karena mengalami langsung suatu proses. Metode belajar aktif menjadi tujuan utama sekolah alam, dimana anak diberi kesempatan belajar dari pengalaman langsung. Pengalaman yang dimiliki anak-anak secara langsung, diharapkan anak tidak mudah bosan, lebih bersemangat, dan lebih tertarik untuk mengeksplorasi pengetahuannya. Lebih jauh, yang diharapkan bukanlah sekedar pada perubahan metode pembelajaran, namun juga perbaikan mutu dan hasil pendidikan. Sistem belajar secara langsung, diharapkan anak menjadi lebih kreatif, berani mengungkapkan pendapat, memupuk rasa ingin tahu, dan terpacu untuk memiliki pengetahuan yang menyeluruh tentang suatu hal. Sekolah alam sangat dibutuhkan dan berpotensi di Surakarta, hanya saja jumlah sekolah alam di Surakarta hanya satu yaitu Sekolah Muhammadiyah Alam Surya Mentari.

\section{Rumusan Permasalahan}

Anak memiliki potensi kreatif sebagaimana anak memiliki dorongan untuk tumbuh dan berkembang. Pertumbuhan dan perkembangan yang berasal dari dorongan dalam diri anak adalah merupakan wujud dari dorongan kreatif. Pengembangan kreativitas dan bakat anak pada dasarnya sejalan dengan pengembangan kepribadian anak yang sehat. Jika kreativitas dan bakat anak berkembang dengan baik, maka anak akan mengalami perkembangan kepribadian yang sehat. Anak akan dapat mengembangkan kepribadian yang mandiri, percaya diri, dan produktif.
Bakat anak dikembangkan menjadi sebuah prestasi tidak akan terjadi dengan sendirinya, tetapi perlu adanya pembinaan dan pengembangan terhadap bakat tersebut sejak dini. Kegiatan outbound membentuk pola pikir yang kreatif, serta meningkatkan kecerdasan emosional dan spiritual dalam berinteraksi. Oleh karena, itu perlu diciptakan lingkungan kondusif untuk anak yang memaksimalkan pendidikan sejak dini, mengembangkan bakat serta kreativitasnya dan juga berekreasi. Permasalahannya adalah :

a. Bagaimanakah model sekolah alam di Surakarta yang mampu meningkatkan daya kreatifitas dan kecerdasan emosional serta spiritual anak?

b. Bagaimanakah menciptakan model sekolah alam di Surakarta yang ramah lingkungan?

\section{KARAKTER ANAK}

Dunia anak adalah dunia bermain, dalam kehidupan anak-anak, sebagian besar waktunya dihabiskan dengan aktivitas bermain. Bermain merupakan suatu kegiatan yang menyenangkan dan spontan sehingga hal ini memberikan rasa aman secara psikologis pada anak. Menurut Wibowo (2007), anak bermain dan bergerak secara aktif, bebas dan spontan karena anak tidak suka diatur dan hanya melakukan kegiatan yang dianggapnya menarik. Berikut ini merupakan karakter kegiatan anak:

\section{a. Bebas Dinamis}

Menurut Conny dalam Wibowo (2007), untuk memaksimalkan perkembangan daya pikir dan kreativitasnya anak tidak perlu diatur dan biarkanlah berbuat sesuka hatinya, namun kebebasan yang diberikan perlu diberi aturan sehingga mudah dikontrol, dijaga dan diarahkan. Agar anak bebas bergerak sesuai dengan keinginannya sebaiknya lingkungan fisik anak harus nyaman dan aman, dimana kegiatan yang dilakukan anak mudah diawasi oleh fasilitator.

b. Aktif, Energik dan selalu ingin tahu

Anak-anak umumnya senang beraktifitas. Anakanak bergerak seolah-olah tidak pernah lelah dan tidak bosan. Anak-anak juga mempunyai rasa keingintahuan yang besar tentang hal-hal yang ada sekitarnya. Mereka memiliki rasa ingin tahu yang tinggi dan antusias terhadap berbagai hal terutama mengenai hal-hal yang baru. Anak selalu mengamati lingkungan untuk menggali pengalaman baru. (Wibowo, 2007)

\section{c. Bermain}

Bermain memberikan kesempatan pada anak untuk mengembangkan kreativitasannya. la dapat berekperimen dengan gagasan-gagasan barunya baik yang menggunakan alat bermain ataupun tidak. Sekali anak merasa mampu menciptakan sesuatu 
yang baru dan unik, anak akan melakukan kembali pada situasi yang lain.

Bermain dapat digunakan anak-anak untuk menjelajahi dunianya, mengembangkan kompetensi dalam usaha mengatasi dunianya dan mengembangkan kreativitas anak. Dengan bermain anak memiliki kemampuan untuk memahami konsep secara ilmiah, tanpa paksaan.

\section{PRINSIP PENDIDIKAN ANAK}

Berdasarkan Petunjuk Teknis Penyelenggaraan Taman Kanak-kanak tahun 2013 berprinsip sebagai berikut:

a. Kegiatan pembelajaran pada anak harus senantiasa berorientasi kepada kebutuhan anak. Anak-anak usia dini adalah anak yang sedang membutuhkan upaya-upaya pendidikan untuk mencapai optimalisasi semua aspek perkembang, baik perkembangan fisik maupun psikis, yaitu intelektual, bahasa, motorik, dan sosio emosional.

b. Belajar melalui bermain. Bermain merupakan sarana belajar anak usia dini. Melalui bermain anak diajak untuk bereksplorasi, menemukan, memanfaatkan, dan mengambil kesimpulan mengenai benda di sekitarnya.

c. Menggunakan lingkungan yang kondusif. Lingkungan harus diciptakan sedemikian rupa sehingga menarik dan menyenangkan dengan memperhatikan keamanan serta kenyamanan yang dapat mendukung kegiatan belajar melalui bermain.

d. Menggunakan pembelajaran terpadu. Pembelajaran pada anak usia dini harus menggunakan konsep pembelajaran terpadu yang dilakukan melalui tema. Tema yang dibangun harus menarik agar anak mampu mengenal berbagai konsep secara mudah dan jelas, sehingga pembelajaran menjadi mudah dan bermakna bagi mereka, membangkitkan minat anak dan bersifat kontekstual.

e. Mengembangkan berbagai kecakapan hidup. Mengembangkan keterampilan hidup dapat dilakukan melalui berbagai proses pembiasaan. Hal ini dimaksudkan agar anak belajar untuk menolong diri sendiri, mandiri dan bertanggungjawab serta memiliki disiplin diri.

f. Mengembangkan berbagai kecakapan hidup. Mengembangkan keterampilan hidup dapat dilakukan melalui berbagai proses pembiasaan. Hal ini dimaksudkan agar anak belajar untuk menolong diri sendiri, mandiri dan bertanggungjawab serta memiliki disiplin diri.

g. Menggunakan berbagai media edukatif dan sumber belajar. Media dan sumber pembelajaran dapat berasal dari lingkungan alam sekitar atau bahan-bahan yang sengaja disiapkan oleh pendidik /guru.

h. Menggunakan berbagai media edukatif dan sumber belajar. Pembelajaran bagi anak usia dini hendaknya dilakukan secara bertahap, dimulai dari konsep yang sederhana dan dekat dengan anak. Agar konsep dapat dikuasai dengan baik hendaknya guru menyajikan kegiatan-kegiatan yang menarik.

\section{ARSITEKTUR UNTUK ANAK Pengaruh Warna Terhadap Perkembangan Anak}

Teori Munsell, menjelaskan bahwa Warna merupakan elemen penting dalam semua lingkup disiplin seni rupa, bahkan secara umum warna merupakan bagian penting dari segala aspek kehidupan manusia. Hal tersebut dapat kita lihat dari semua benda yang dipakai oleh manusia, semua peralatan, pakaian, bahkan alam disekeliling kita merupakan benda yang berwarna. Karena begitu penting peranan warna bagi manusia warna sering kali dipakai sebagai elemen estetis, representasi dari alam, dan sebagai alat komunikasi, serta berekspresi. (Daniar Wikan Setyanto, 2009)

Warna adalah salah satu sarana kita untuk melatih keutuhan persepsi terhadap ruang, karena berbagai kombinasinya dapat menghasilkan sejumlah petunjuk bagi anak-anak untuk memperkirakan jarak dan kedalaman. Penting untuk dipahami bahwa seorang anak belum mempunyai persepsi yang utuh mengenai ruangan. Anak mengamati detail-detail dari bagian ruangan yang disenangi, apakah itu furnitur, warna-warna pada dinding sekolah atau unsur-unsur ruangan lainnya, kemudian anak mencoba menangkap suasana yang diciptakan untuk ruangan kelas tersebut secara menyeluruh. Jadi dalam menciptakan suasana di dalam suatu ruangan sekolah taman kanak-kanak lebih dipentingkan penampilan dari tiap-tiap unsur ruang secara maksimal. Dengan demikian dapat merangsang keinginan anak untuk tinggal dalam ruangan, penciptaan suasana yang ingin dicapai dalam ruangan tersebut merupakan hal yang kedua. Warna pada anak usia dini merupakan hal sangat penting bagi perkembangan saraf otaknya. Selain memancing kepekaan terhadap penglihatan, warna juga bermanfaat untuk meningkatkan daya pikir serta kreativitas anak.

Sari (dalam Putri, 2012), mengemukakan bahwa penggunaan warna yang tepat untuk sekolah dapat meningkatkan proses belajar mengajar untuk siswa maupun gurunya. Suatu lingkungan yang dirancang dengan baik bukan hanya memberi kemudahan belajar tetapi juga dapat mengurangi masalahmasalah perilaku yang negatif. Hal ini disebabkan warna menimbulkan kesan-kesan tertentu dalam menciptakan suasana ruang dan warna dapat 
menimbulkan pengaruh terhadap jiwa anak-anak, baik secara langsung maupun tidak langsung, misalnya perasaan gelisah, nyaman, panas, dan sebagainya Karena hal-hal tersebut perlu diketahui pengaruh warna-warna tertentu terhadap anak-anak, dengan demikian dapat memperkecil bahkan mencegah terjadinya kesalahan di dalam menempatkan warna-warna yang mempunyai pengaruh negatif, khususnya terhadap perkembangan fisik dan mental anak. Penggunaan warna yang menarik juga bisa didapat langsung dari alam dengan menempatkan bunga-bunga dengan warna cerah.

Putri (2012) mengatakan bahwa peran warna dalam mendukung program belajar mengajar di taman kanak-kanak tidak hanya dalam hal menciptakan suasana emosional saja, akan tetapi dalam banyak hal warna dapat berperan, antara lain:

a. Stimuli

Warna berperan sebagai rangsangan anak untuk beraktivitas dan berimajinasi dengan menggunakan warna cerah yang disukai anak dan menarik perhatian mereka, baik pada mainan akan ataupun warna ruang (lihat gambar 1 dan 2).

b. Evaluasi perkembangan anak

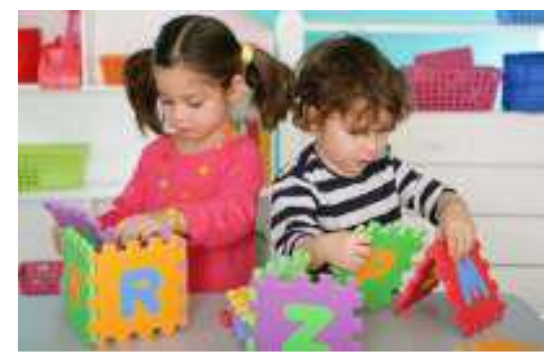

Gambar 1. Anak Bermain dengan Puzzle Warna. Sumber: http://kesehatangizianak.com/, diakses 15 Maret 2015.

Warna merupakan sebuah elemen penting untuk mengevaluasi perkembangan anak, misalnya anak-anak diberi benda-benda dengan bentuk sama tetapi warna berbeda atau sebaliknya bentuk beda dan warna sama, puzzles, berbagai figur, dan sebagainya.

c. Memfokuskan dan Mengalihkan Perhatian

Warna cerah dan menarik akan memfokuskan perhatian anak sedangkan warna gelap seperti coklat dan abu-abu dapat mengalihkan perhatian anak.

d. Mengatur ruang agar tampak lebih luas atau mengecil.

Warna dingin bila digunakan untuk mewarnai ruangan akan memberikan ilusi jarak, akan terasa mundur. Sebaliknya warna hangat, terutama keluarga merah akan terasa seolah-olah maju, memberikan kesan jarak yang lebih pendek. Warna-warna cerah membuat objek kelihatan lebih besar dan ringan dari pada sesungguhnya. Sementara warna gelap membuat mereka lebih kecil dan berat.

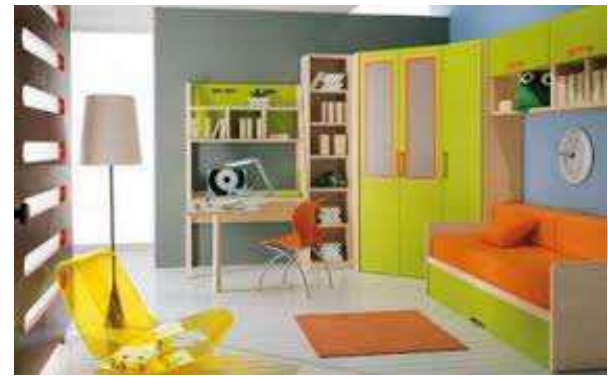

Gambar 2. Warrna Cerah Pada Ruang Belajar Anak. Sumber: http://www.al-maghribicendekia.com/, diakses 15 Maret 2015.

e. Menciptakan rasa hangat, dingin, tenang dan riang

Penggunaan komposisi warna-warna cerah dan warna-warna kontras pada ruang akan menciptakan suasana gembira atau riang.

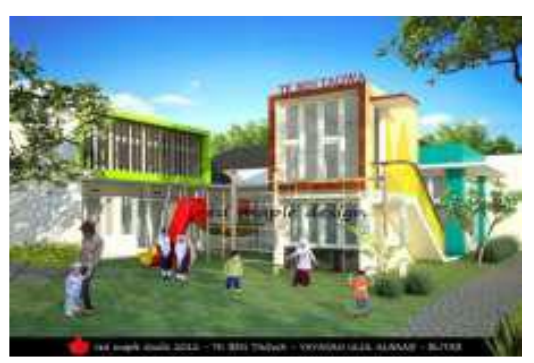

Gambar 3. Penggunaan Warna Cerah untuk Menciptakan Suasana Riang.

Sumber: http://tipsproperti.com/, diakses 15 Maret 2015.

Pentingnya unsur warna bagi anak-anak diungkapkan oleh Crow (dalam Putri 2012) bahwa dalam menciptakan suasana suatu ruangan faktor warna dan bentuk merupakan penampilan pertama yang dapat dinikmati, sebab kedua faktor ini langsung berhubungan dengan penglihatan tanpa melalui proses penghayatan terlebih dahulu, bagi anak-anak yang mempunyai taraf penghayatan yang masih terlalu sederhana, maka yang dapat dinikmati sebagai unsur suasana hanyalah faktor warna dan bentuk saja.

\section{Studi Komparasi}

\section{a. Sekolah Citra Alam Ciganjur}

Bangunan di Sekolah Citra Alam Ciganjur ini dikelompokkan dalam sistem cluster sesuai dengan fungsi dan pewadahan kegiatannya (lihat gambar 4). Setiap cluster terdapat ruang terbuka hijau yang berfungsi sebagai area rekreasi, belajar, orientasi siswa dan juga sebagai penghubung antar bangunan. Setiap ruang kelas terorientasi dengan ruang luar 
sehingga terdapat harmonisasi dengan alam sebagai objek pembelajaran.

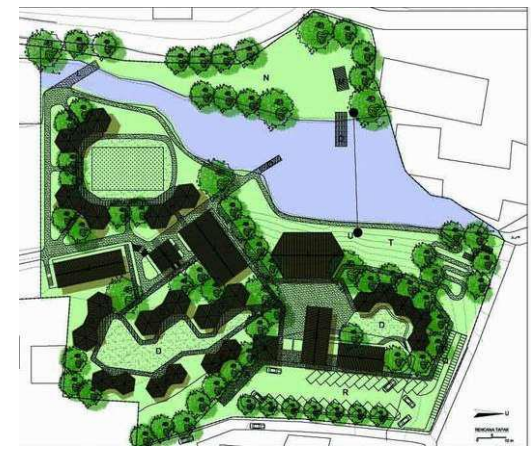

Gambar 4. Site Plan Sekolah Alam Ciganjur Sumber: http://rizkiarc11.blogspot.com/, diakses 12 Maret 2015.

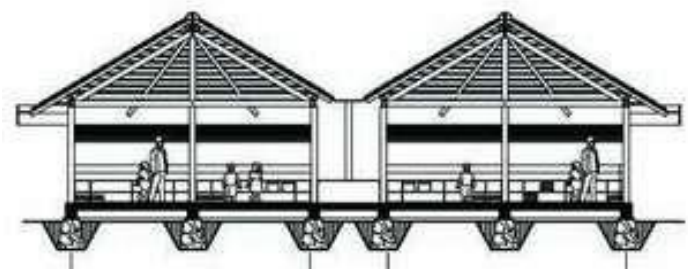

Gambar 5. Potongan Sekolah Alam Ciganjur Sumber: http://rizkiarc11.blogspot.com/, diakses 12 Maret 2015.

Konsep rumah panggung (lihat gambar 5) dipilih untuk menyiasati bentuk lahan yang berkontur. Keseluruhan luas lantai bangunan sekolah alam ini sekitar $3500 \mathrm{~m}^{2}$

\section{b. Green School Bali}

Green School Bali didirikan pada tahun 2006 oleh John Hardy. Sekolah dibuka pada September 2008 dengan 90 siswa dan sebelumnya merupakan lahan perkebunan dan sawah. Sejak saat itu secara fisik dan jumlah murid terus mengalami peningkatan setiap tahun.

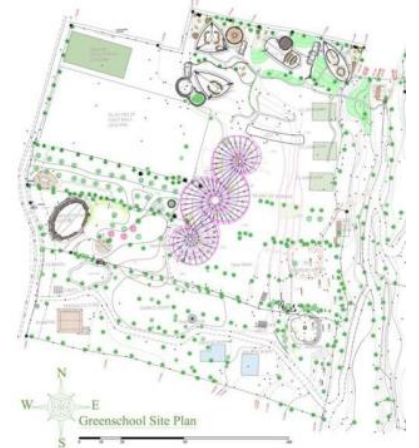

Gambar 6. Site plan Greenschool Bali.

Sumber: http://openbuildings.com/, diakses 12 Maret 2015.

Secara keseluruhan konsep pada tapak adalah cluster dengan pengelompokan tipe bangunan berdasarkan fungsi dan aktivitas. Setiap bangunan mempunyai lapangan sebagai area terbuka. Jalan setapak yang menghubungkan tiap bangunan apa adanya dan juga tidak diaspal.

Sekolah ini melakukan inovasi dengan mengambil bentuk unik yang tidak akan ditemukan di sekolah lain. Material utama dari bangunan di sekolah ini adalah bambu, alang-alang, rumput gajah, dan tanah liat di atasnya (lihat gambar 6). Semua konstruksinya merupakan material alam yang dapat di daur ulang dan juga mempunyai nilai kelokalan. Ruang kelas di desain tanpa sekat dan dinding beton sehingga memaksimalkan penghawaan alami. Green School di Bali, Indonesia memberikan pendidikan alam, holistik dan berpusat pada siswa. Meskipun mata pelajaran konvensional juga turut diajarkan, Green School lebih menekankan pada metode pendidikan yang berbasis holistik, mempersiapkan siswa siswinya menjadi individu yang kritis, kreatif, serta sadar lingkungan. Ini berarti, selain mempelajari algoritma, para siswa.

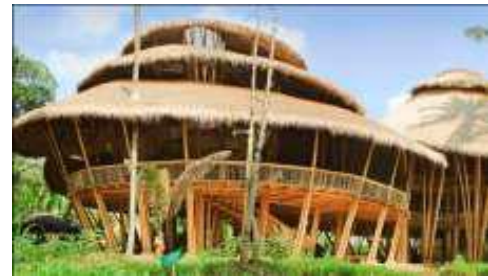

Gambar 7. Tampak Greenschool Bali.

Sumber: http://www.archdaily.com/, diakses 12 Maret 2015.

\section{c. Sekolah Alam Insan Mulia Surabaya}

Sekolah Alam Insan Mulia Surabaya (SAIMS). menerapkan model pembelajaran yang membuat anak tetap riang gembira di saat sekolah berlangsung (joyful learning). Prinsip dasarnya adalah anak akan belajar secara efektif bila dia berada dalam kondisi fun dan nyaman. Sekolah didesain menjadi tempat belajar yang menyenangkan sehingga anak menjadi kerasan. Siswa tidak hanya belajar di dalam kelas, tetapi juga belajar di ruang terbuka, alam bebas maupun di arena bermain edukatif. Di SAIMS siswa belajar kecakapan hidup (life skill) secara utuh tidak parsial seperti di sekolah konvensional.
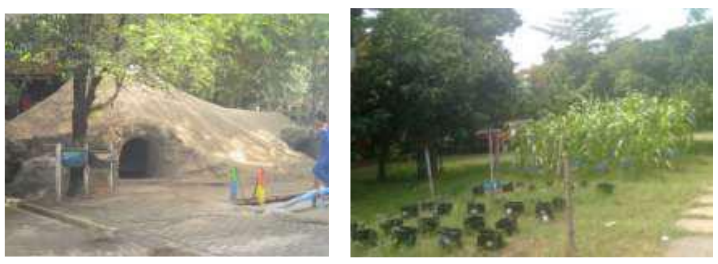

Gambar 8. Salah Satu gua ruang pembelajaran anak dan Area pembelajaran bercocok tanam di SAIMS Sumber : data lapangan, 2011

Ruang kelas digunakan sebagai ruang multifungsi untuk kegiatan belajar-mengajar dan juga bermain anak. Interior kelas di cat dengan warna 
cerah untuk merangsang anak untuk kreatif dalam belajar. Furniture seperti papan tulis, meja, dan kursi digunakan menyesuaikan dengan skala tubuh anak. Terdapat area di dinding untuk memamerkan hasil karya anak.

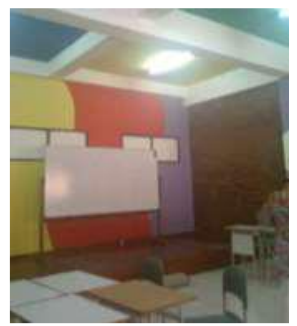

Gambar 9. Ruang Kelas di SAIMS

Sumber : data lapangan, 2015

\section{d. TK Lazuardi GIS Kamila Surakarta}

TK Lazuardi GIS Kamila Surakarta menggunakan kombinasi challange curriculum yaitu kegiatan pembelajaran berbasis sentra yang telah disesuaikan dengan kebutuhan tumbuh kembang anak dan catalyst curriculum yaitu kegiatan belajar yang diusulkan oleh anak didik berdasarkan permasalahan dan kebututhan yang sedang dihadapi anak.

Fasilitas ruang kelas di cat dengan warna biru memberikan kesan sejuk dan tenang dengan ornamen. Terdapat juga karya siswa yang digantung sebagai pemanis interior. Lantai ditutupi dengan karpet untuk menambah faktor keamanan anak.

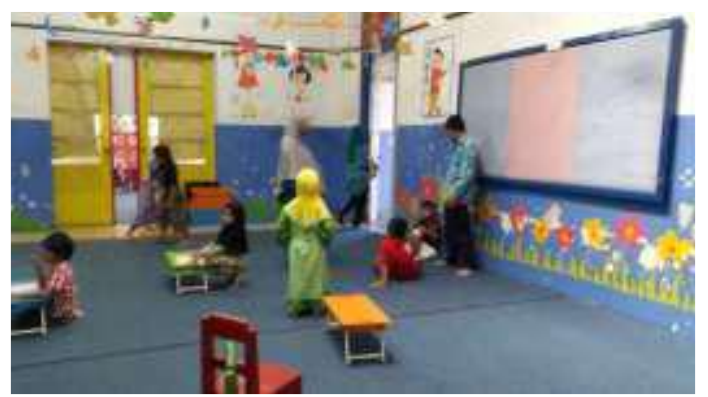

Gambar 10. Ruang kelas di TK Lazuardi. Sumber: data lapangan, 2015.

\section{METODE PENELITIAN}

\section{Studi literatur}

Studi literature dilakukan untuk mendapatkan landasan teori tentang standart standart sekolah alam untuk anak-anak.

\section{Studi komparasi}

Studi komparasi dilakukan untuk mendapatkan gambaran sekolah alam yang terdapat di Indonesia.

\section{PEMBAHASAN}

\section{Gagasan Perancangan}

Children Activity Center merupakan fasilitas edukasi berbasis alam di Surakarta dengan kegiatan utama berupa pengasuhan anak, edukasi, rekreasi, sosialisasi serta penyaluran bakat dan kreativitas yang dapat mendukung pertumbuhan anak baik secara fisik maupun mental dengan pendekatan alternatif pendidikan berbasis alam. Kegiatan utama berupa pendidikan yang difokuskan pada anak usia dini yaitu 3-6 tahun. Kegiatan pengasuhan diperuntukkan bagi anak usia 1 hingga 2 tahun. Bangunan berfungsi untuk memberikan fasilitas pengasuhan dan penitipan anak bersifat edukatif dan menyenangkan, sebagai sarana pendidikan anak usia dini dengan konsep pembelajaran berbasis alam, dan sebagai sarana pengembangan bakat dan kreativitas anak melalui kegiatan bermain sambil belajar.

Potensi Children Activity Center ini adalah:

\section{a. Sebagai Child-day Care}

Penduduk wanita di Surakarta yang bekerja berjumlah 111.871 jiwa atau sebesar $43.05 \%$ dari total penduduk yang bekerja. Sedangkan berdasarkan data penduduk berusia kurang dari 15 tahun cukup besar yaitu lebih dari seperlima penduduk Kota Surakarta $(22,72$ persen). Hal ini harus menjadi perhatian karena ketika ibu menjadi wanita karir peran ibu dalam pengasuhan anak secara sementara harus diambil alih oleh pihak lain. Child day Care menjadi pilihan utama sebagai alternatif dalam pengasuhan, merawat dan mendidik anak agar perkembangan dan pertumbuhannya maksimal.

\section{b. Sebagai pusat pendidikan anak usia dini}

Jumlah Taman Kanak-kanak di Surakarta masih sedikit. SNI telah menetapkan bahwa keberadaan satu TK adalah dalam jumlah per 1250 jiwa. Children Acitivy Center berpotensi sebagai Pusat Pendidikan Anak Usia Dini untuk memenuhi kebutuhan anak dalam hal pendidikan di Surakarta.

c. Sebagai Pariwisata Edukasi

Children Acitivy Center berpotensi sebagai pusat pariwisata berbasis edukasi di Surakarta dan khususnya di Laweyan. Fasilitas pariwisata di Kecamatan Laweyan hanya terdapat 3 buah saja yaitu terdiri dari museum dan taman hiburan rakyat. Children Acitivy Center direncakan akan dilengkapi dengan fasilitas outboond, smart center dan juga perpustakaan yang dapat dinikmati oleh siswa maupun oleh masyarakat umum.

\section{Konsep Perancangan}

a. Konsep Tata Masa

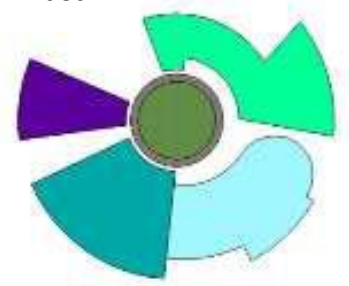

Gambar 11. Konsep pola tata massa bangunan. Sumber: Analisa penulis, 2015 
Tata massa terkonsep pada pola radial dengan bentuk melingkar di bagian center dalam site, sebagai titik center dan massa bangunan di sekelilingnya untuk memudahkan mobiltas pengguna.

\section{b. Konsep Landscape}

Terdapat tanaman hias untuk menambah faktor estetika. Menggunakan taman bunga dengan warna mencolok dan bau yang berbeda-beda dimaksudkan agar menjadi media pembelajaran siswa. Tanaman hias menggunakan Sutra Bombay dan Taiwan Beauty serta penutup dengan menggunakan rumput gajah mini.
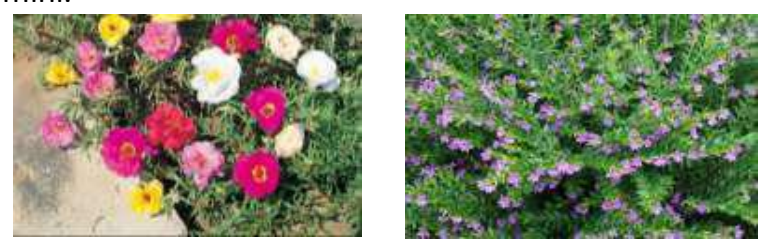

Gambar 12. Sutra Bombay dan Taiwan Beauty.

Sumber: http://rooang.com/, diakses 15 April 2015.

Pada area barat ditanam pohon dengan karakteristik berdaun rindang seperti pohon tanjung karena dapat dimanfaatkan sebagai peneduh dan dapat juga berfungsi sebagai barrier suara bising. Pada sisi selatan ditanam bambu sebagai pagar dan juga diberi pohon akasia sebagai penyerap polusi udara dari jalan. Area farming dinaungi oleh pohon yang berbuah yang dapat dimanfaatkan sebagai bahan pembelajaran siswa seperti pohon rambutan, mangga, jambu, markisa, dan talok serta dilengkapi dengan sawah, kolam ikan, peternakan sapi, dan peternakan ayam. Area pedestrian dilengkapi dengan shelter tumbuhan maupun shelter dari bambu. Untuk jalurnya menggunakan grass block sehingga air tetap dapat masuk ke tanah. Site dilengkapi dengan teknologi biopori sehingga hujan yang masuk ditampung dan diolah sehingga dapat dimanfaatkan untuk menyiram tanaman maupun untuk toilet.

c. Konsep Ruang

Ruang kelas menggunakan material kayu dan bambu dengan konsep kelas saung di area terbuka.

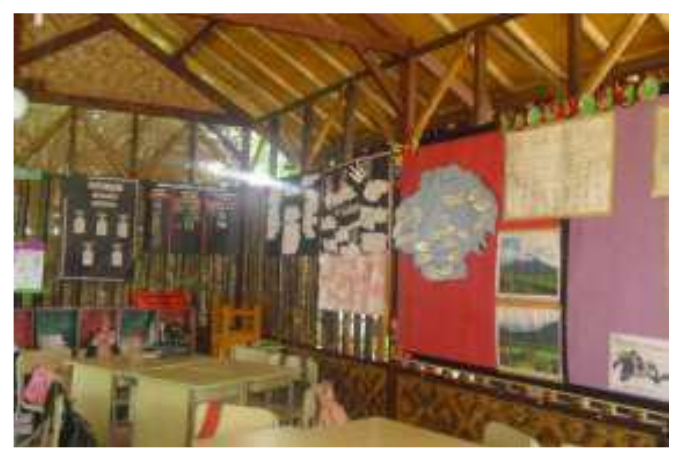

Gambar 13. Ruang Kelas.

Sumber: http://www.sekolahkreativa.com/, diakses 16 April 2015.
Area Outbond dilengkapi dengan fasilitas yang bermanfaat untuk mendekatkan diri dengan alam dan juga melatih kemandirian, sosial dan kepercayaan diri anak.

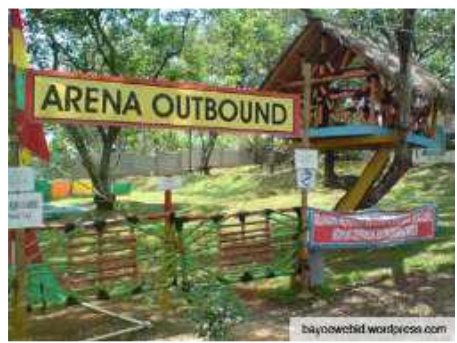

Gambar 14. Area Outbound.

Sumber: http://mommiestories.com/, diakses 16 April 2015.

d. Konsep Penampilan Bangunan

Pagar terbuat dari bambu. Tanaman bambu dapat berfungsi sebagai barrier suara dan juga merupakan material yang disediakan oleh alam. Bangunan penerima dan pengelola menggunakan material bambu dan kayu memberikan kesan menyatu dengan alam. Untuk bagian atap menggunakan bahan ijuk yang dibuat bertumpuk. Ruang kelas merupakan saung dari kayu dan bambu tanpa dinding.

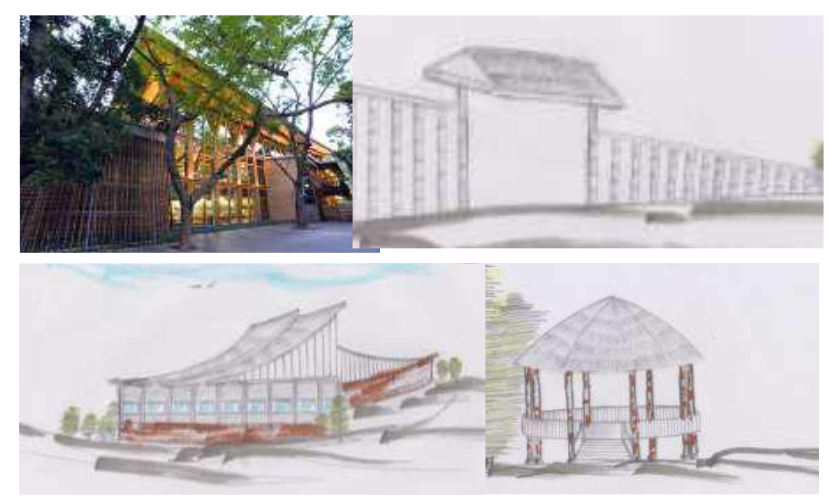

Gambar 15. Gambar Tampilan Bangunan Sumber: Analisis, 2015

e. Konsep interior

Ruang penerima adalah ruang untuk menerima seluruh user yang akan memasuki bangunan Children Activity Center. Di dalam ruang penerima terdapat lobby dan ruang tunggu yang dicat dengan warna putih dan juga furniture berwarna terang seperti ungu dan kuning. Lantai dapat menggunakan keramik sedangkan dinding dari batu bata tanpa cat dan plafond dari kayu untuk. memberikan kesan modern namun tetap natural. Ruang kelas merupakan ruang untuk proses kegiatan pembelajaran. Ruang kelas terdiri dari saung yang menggunakan lantai kayu dan dinding batu bata tanpa finishing memberikan kesan hangat dan juga menyatu dengan alam. Pemberian warna yang dapat dari karya siswa yang digantung di dinding sebagai pemanis interior. Ruang untuk mengasah bakat dan kreativitas menggunakan saung 
sebagai ruang belajar memberikan kesan menyatu dengan alam. Selain itu furnitur yang ada tetap menggunakan warna cerah untuk meningkatkan semangat dan kemauan anak dalam belajar. Ruang pengasuhan terdiri dari area bermain dan juga ruang tidur untuk anak. Area bermain menggunakan warna cerah seperti hijau dan kuning. Sedangkan area tidur menggunakan warna dingin dan tenang seperti biru. Ruang perpustakaan dibuat dengan banyak bukaan dan jendela kaca untuk memaksimalkan penghawaan dan pencahayaan alami. Lantai dan plafond dari kayu tetapi furniture tetap menggunakan warna cerah. Ruang pengelola merupakan area kantor bagi guru, instruktur dan juga staff di Children Activity Center. Ruang pengelola terkonsep pada interior minimalis yang menggunakan warna abu, coklat dan putih. Pencahayaan alami dimaksimalkan dengan adanya jendela dan juga skylight.

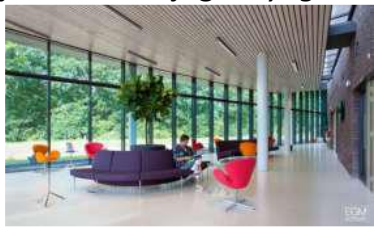

Ruang Penerima

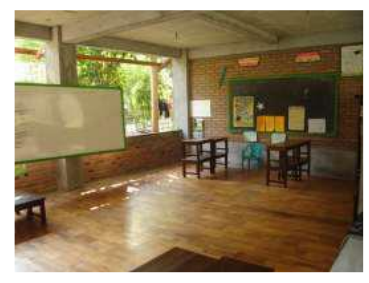

Ruang Kelas

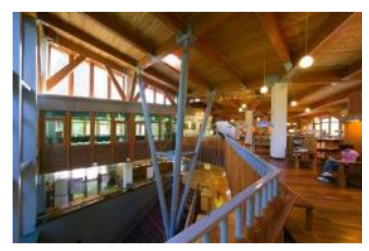

Ruang Perpustakaan

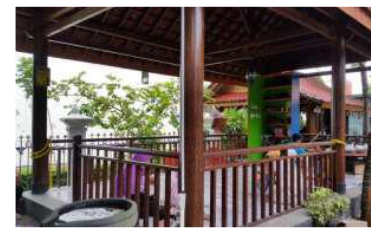

Saung ruang bakat

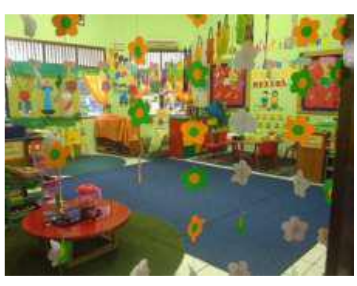

Ruang pengasuhan/bermain

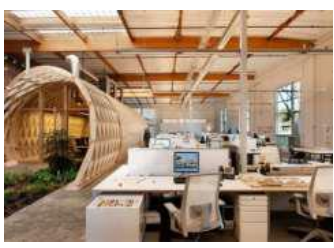

Ruang Pengelola
Gambar 16. Gambar Konsep Interior Sumber: Analisis, 2015

\section{KESIMPULAN}

Sekolah Alam untuk anak anak semakin lama semakin diminati oleh masyarakat. Selain untuk pendidikan anak juga memberi kesempatan untuk orang tua untuk menitipkan dengan rasa aman. Model yang disarankan adalah dengan :

a. Tata massa terkonsep pada pola radial dengan bundaran di site sebagai titik center dan massa bangunan di sekelilingnya untuk memudahkan mobiltas pengguna.

b. Masa bangunan dilengkapi dengan fasilitas yang berupa ruang penerima, saung ruang bakat, saung ruang kelas, ruang pengasuhan/ bermain, ruang perpustakaan dan ruang pengelola. c. Terdapat tanaman hias untuk menambah faktor estetika. Taman taman bunga menggunakan warna mencolok dan bau yang berbeda-beda dimaksudkan agar menjadi media pembelajaran siswa.

d. Ruang kelas menggunakan material kayu dan bambu dengan konsep kelas saung di area terbuka.

e. Terdapat ruang outbond agar anak lebih dekat dengan alam.

f. Penampilan bangunan menggunakan material alam seperti bambu dan kayu.

g. Interior menggunakan warna warna terang disamping material alami hal ini diharapkan mampu untuk merangsang penglihatan pada anak dan memberi efek ceria.

\section{DAFTAR PUSTAKA}

Ahmad Hamadani,2015, Sekolah Alam: Alternatif Pendidikan Ramah Anak, Jurnal Harkat Media Komunikasi Gender, 11(1) 2015, LP2M, UIN Syarif Hidayatullah, Jakarta.

Daniar Wikan Setyanto, 2009, Teori Warna, Daniar wikan blogspot.com, 2009,2,teori warna html.

Putri, Ria Hapsari. 2012. Center of Early Childhood Education in Solo dengan Penekanan Teori Warna. Laporan Dasar-dasar Program Perencanaan dan Perancangan Arsitektur Universitas Muhammadiyah Surakarta.

Rohinah, 2014, Sekolah Alam: Paradigma Baru Pendidikan Islam Humanis, Nadwa, Jurnal Pendidikan Islam, Vol 8, No 2/ tahun 2014,

Wibowo, Ariyanto. 2007. Kid's Corner di Kudus. Laporan Dasar-dasar Program Perencanaan dan Perancangan Arsitektur Universitas Muhammadiyah Surakarta.

http://mommiestories.com/, diakses 16 April 2015. http://rooang.com/, diakses 15 April 2015.

http://www.sekolahkreativa.com/, diakses 16 April 2015.

http://www.archdaily.com/, diakses 12 Maret 2015 http://openbuildings.com/, diakses 12 Maret 2015. http://rizkiarc11.blogspot.com/, diakses 12 Maret 2015

http://kesehatangizianak.com/, diakses 15 Maret 2015

http://www.al-maghribicendekia.com/, diakses 15 Maret 2015

http://tipsproperti.com/, diakses 15 Maret 2015. http://www.archdaily.com/, diakses 12 Maret 2015 